\title{
PENGARUH BIAYA TRANSAKSI TERHADAP KEUNTUNGAN USAHATANI KEDELAI DI KABUPATEN LAMONGAN, JAWA TIMUR
}

\author{
Hardiyanti Sultan ${ }^{1)}$, dan Dwi Rachmina ${ }^{2)}$ \\ ${ }^{1,2)}$ Departemen Agribisnis, Fakultas Ekonomi dan Manajemen, Institut Pertanian Bogor \\ ${ }^{1)}$ hardiyantisultan91@gmail.com
}

\begin{abstract}
Transaction cost is one of the characteristics of imperfect market. Transaction cost on soybean farming will affect the level of profit soybean farming. The purpose of this research were to analyze the transaction cost structure and the effect of transaction cost on the profitability of soybean farming. Research method used Transaction Cost Analysis and multiple linear regression. This research was held in Lamongan, Jawa Timur and interviewed 120 soybean farmers to derive the data. The results showed that the transaction cost component on soybean farming consists of (1) information cost; (2) negotiation cost; (3) coordination cost; (4) enforcement cost; (5) monitoring cost and (6) risk cost. The amount of the transaction cost that are formed on soybean farming was Rp144.120,86. Negotiation cost was the highest cost of transaction cost component that was $60,30 \%$, followed by information cost $14,07 \%$, coordination cost $12,22 \%$, enforcement cost $8,03 \%$, monitoring cost $4,23 \%$ and risk cost $1,15 \%$. Transacion cost have a negative and significant effect on the profitability of soybean farming.
\end{abstract}

Keyword(s): imperfect market, transaction cost, farming profit

\begin{abstract}
ABSTRAK
Biaya transaksi merupakan salah satu ciri imperfect market. Biaya transaksi pada usahatani kedelai akan berpengaruh terhadap tinggi rendahnya keuntungan usahatani kedelai. Tujuan penelitian ini adalah untuk menganalisis struktur biaya transaksi dan pengaruh biaya transaksi terhadap keuntungan usahatani kedelai. Metode penelitian menggunakan Transaction Cost Analysis dan regresi linear berganda. Penelitian dilakukan di Kabupaten Lamongan, Jawa Timur dengan jumlah responden 120 petani kedelai. Hasil penelitian menunjukkan bahwa komponen biaya transaksi pada usahatani kedelai di Kabupaten Lamongan terdiri dari (1) biaya informasi; (2) biaya negosiasi; (3) biaya koordinasi; (4) biaya pelaksanaan; (5) biaya monitoring dan (6) biaya risiko. Jumlah biaya transaksi yang terbentuk pada usahatani kedelai sebesar Rp 144.120,86. Biaya negosiasi merupakan komponen biaya transaksi yang memiliki persentase tertinggi yaitu $60,30 \%$, selanjutnya biaya informasi $14,07 \%$, biaya koordinasi $12,22 \%$, biaya pelaksanaan 8,03\%, biaya monitoring 4,23\% dan biaya risiko 1,15\%. Biaya transaksi berpengaruh negatif dan signifikan terhadap keuntungan usahatani kedelai.
\end{abstract}

Kata Kunci: imperfect market, transaction cost, keuntungan usahatani

\section{PENDAHULUAN}

Biaya transaksi adalah biaya selain harga barang/jasa yang dikeluarkan dalam perdagangan barang/jasa. Biaya transaksi ini terjadi karena adanya informasi yang tidak sempurna (imperfect information) dan keterbatasan dalam mengolah informasi tersebut. Biaya 
transaksi dikategorikan sebagai biaya yang dikeluarkan diluar atau selain dari biaya produksi. Keberadaan biaya ini akan meningkatkan total biaya yang akan dikeluarkan dalam sebuah usaha. Tingginya biaya yang akan dikeluarkan pelaku usaha karena adanya biaya transaksi akan mengakibatkan perbedaan harga yang diterima oleh konsumen dan harga yang diterima oleh produsen.

Coase dalam Moss (2013) mengatakan bahwa biaya transaksi adalah biaya yang tidak dapat terhindarkan. Setiap pertukaran yang terjadi baik pertukaran barang/jasa ataupun pertukaran informasi akan menghasilkan sebuah biaya pertukaran yaitu biaya transaksi. Keberadaan biaya transaksi akan membuat pengalokasian dana untuk biaya yang harus dikeluarkan akan semakin bertambah. Namun hal ini dapat berkontribusi dalam perbaikan usaha itu sendiri sebab dengan teridentifikasinya biaya transaksi maka keuntungan usaha bisa dikendalikan dengan baik.

Beberapa kasus mengenai perdagangan barang/jasa khususnya perdagangan dalam skala kecil seperti perdagangan produk pertanian yang berada di pedesaan, biaya transaksi ini sulit untuk diidentifikasi oleh pelaku usaha. Berge et. al. (2011) mengemukakan bahwa rendahnya tingkat pendidikan pelaku usaha di pedesaan mengakibatnya sulitnya pelaku usaha untuk membedakan atau mengklasifikasikan semua bentuk biaya yang akan atau telah dikeluarkan. Kesulitan identifikasi ini akan mengurangi keuntungan yang akan diterima oleh pelaku usaha karena tanpa sadar telah mengeluarkan beberapa biaya lainnya diluar biaya produksi yang tidak dipertimbangkan dan tidak dialokasikan sebelumnya. D’Hondt (2008) mengatakan bahwa biaya transaksi yang rendah secara otomatis akan meningkatkan keuntungan yang dalam hal ini berarti bahwa peningkatan biaya transaksi akan menurunkan tingkat keuntungan. Oleh sebab itu, biaya transaksi pada akhirnya akan mengakibatnya terjadinya inefisiensi keuntungan yang akan diterima oleh pelaku usaha atau produsen.

Keterlibatan petani baik dalam lembaga pembiayaan atau lembaga lainnya yang terlibat dalam pemasaran usahatani kedelai diduga akan menimbulkan biaya transaksi yang kemudian akan berpengaruh terhadap tinggi rendahnya keuntungan usaha. Dalam pengertian sempit, pemasaran pertanian akan menunjukkan aktivitas distribusi suatu produk dari tingkat usahatani sampai ke tangan konsumen akhir. Kemunculan biaya transaksi dalam aktivitas ini diduga tidak mampu diidentifikasi oleh petani sehingga akan berpengaruh pada keuntungan usaha Sebagaimana dikatakan oleh Baye (2010) bahwa biaya transaksi muncul karena adanya ketidaksempurnaan informasi (imperfect information) dan keterbatasan dalam mengolah informasi tersebut.

Pemilihan usahatani kedelai sebagai objek penelitian disebabkan kedelai merupakan salah satu dari lima komoditi pangan utama (beras, jagung, kedelai, gula dan daging sapi) di Indonesia (Badan Pusat Statistik, 2014). Selain itu kedelai merupakan sumber protein nabati utama bagi sebagian besar penduduk Indonesia. Bagi perekonomian Indonesia kacang 
kedelai memiliki peranan yang besar karena merupakan sumber bahan baku utama bagi industri tahu, tempe, dan pakan ternak berupa bungkil kacang kedelai. Data dari Badan Pusat Statistik (BPS) menunjukkan bahwa produksi kedelai dalam 5 tahun terakhir terus mengalami penurunan. Sedangkan kebutuhan kedelai dalam negeri cenderung mengalami peningkatan, misalnya kebutuhan kedelai tahun 2010 mencapai 2.647.151 ton sedangkan produksi kedelai hanya mampu mencapai 907.031 ton. Hal ini diduga terjadi karena rendahnya keuntungan yang didapatkan petani untuk produk kedelai sehingga petani memilih untuk membudidayakan komoditi lain misalnya kangkung.

Salah satu kabupaten yang menjadi pemasok kedelai untuk Provinsi Jawa Timur adalah Kabupaten Lamongan. Walaupun bukan sebagai penghasil utama, namun Kabupaten Lamongan merupakan daerah yang secara kontinu memproduksi kedelai sehingga dinilai bahwa kabupaten ini dapat memberikan gambaran secara umum mengenai kondisi usahatani kedelai di Jawa Timur. Beberapa kegiatan yang diduga akan memunculkan biaya transaksi adalah pada kegiatan pengadaan sumbr pembiayaan, pengadaan input dan juga pada kegiatan penjualan output.

Pada kegiatan pengadaan input, biaya transaksi diduga akan mempengaruhi harga input sedangkan pada kegiatan penjualan output, biaya transaksi diduga akan mempengaruhi harga output. Perubahan harga input dan harga output ini kemudian diduga akan berpengaruh terhadap tingkat keuntungan usahatani kedelai.

Salah satu kegiatan yang diduga akan mempengaruhi harga input adalah pada pengadaan tenaga kerja luar keluarga. Pada saat musim panen, permintaan terhadap tenaga kerja luar keluarga sangat tinggi sehingga petani membutuhkan informasi dari berbagai pihak yang mengetahui tentang buruh tani borongan. Terkadang petani harus mencari ke kabupaten lainnya disebabkan buruh tani di Kabupaten Lamongan sudah dipekerjakan oleh petani lainnya. Pencarian informasi hingga mendapatkan buruh tani yang sesuai diduga memunculkan biaya transaksi. Pengaruh biaya transaksi yang ditimbulkan ini tentunya sangat berpengaruh terhadap harga input usahatani kedelai yaitu pada pengadaan tenaga kerja luar keluarga.

Selain mempengaruhi harga input, biaya transaksi juga mempengaruhi harga output. Kegiatan usahatani yang diduga akan memunculkan biaya transaksi yang berpengaruh terhadap harga output adalah kegiatan mencari informasi harga kedelai. Lokasi usahatani kedelai di Kabupaten Lamongan sebagian besar berada jauh dari pasar sebagai lokasi perdagangan kedelai. Pasar untuk kedelai terdapat di perkotaan dan juga beberapa berada diluar kabupaten. Sistem pemasaran kedelai di Kabupaten Lamongan dimulai dari penjualan kedelai oleh petani kedelai kepada pedagang perantara (tengkulak) di tingkat desa. Kondisi ini menyebabkan petani sangat bergantung pada informasi harga yang dimiliki oleh pedagang perantara sebagaimana diketahui bahwa pedagang 
perantara lebih menguasai harga pasar daripada petani. Untuk mengetahui harga kedelai, petani akan berupaya untuk mendapatkan informasi harga baik melalui petani lainnya ataupun langsung melalui pedagang desa atau pedagang kecamatan. Kegiatan mencari informasi inilah yang digolongkan sebagai biaya transaksi. Berapapun jumlah biaya transaksi yang ditimbulkan pada kegiatan ini diduga akan berpengaruh terhadap harga output yang berlaku.

Berdasarkan uraian latar belakang tersebut, penelitian ini bertujuan untuk: 1) Menganalisis struktur biaya transaksi yang terdapat dalam kegiatan usahatani kedelai, 2) Menganalisis faktor-faktor yang mempengaruhi keuntungan usahatani dan pengaruh biaya transaksi terhadap keuntungan usahatani.

\section{METODE PENELITIAN}

Penelitian dilakukan di Kabupaten Lamongan, Jawa Timur. Pemilihan lokasi ini dilakukan dengan pertimbangan karena daerah tersebut merupakan salah satu sentra produksi kedelai di Jawa Timur. Waktu penelitian pada bulan Agustus 2014 hingga Maret 2015.

Metode pengumpulan data primer dilakukan melalui wawancara langsung kepada petani responden dengan menggunakan kuesioner. Penentuan responden dilakukan dengan metode simple random sampling dengan pembagian proporsi yang rata untuk setiap kecamatan. Metode ini dilakukan karena telah terdapat sampling frame untuk masing-masing kecamatan terpilih. Jumlah keseluruhan sampel adalah 120 petani kedelai yang berasal dari
Kecamatan Tikung sebanyak 50 orang, Kecamatan Kembangbahu sebanyak 18 orang dan Kecamatan Mantup sebanyak 52 orang.

Persamaan yang digunakan untuk menghitung komponen dan rasio biaya transaksi:

$$
\begin{gathered}
\operatorname{Tr} C=\sum Z i \\
Z=\frac{Z i}{\operatorname{Tr} C}: \sum Z i=1
\end{gathered}
$$

Sedangkan persamaan regresi linear berganda yang digunakan untuk melihat faktor-faktor yang mempengaruhi keuntungan usahatani sebagai berikut:

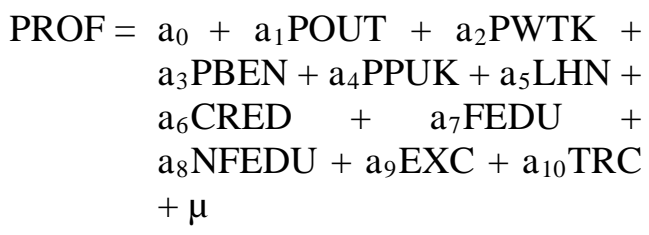

$\left(a_{0}, a_{1}, a_{5}, a_{6}, a_{7}, a_{8}, a_{9}>0\right.$ dan $a_{2}, a_{3}, a_{4}$, $\left.\mathrm{a}_{10}<0\right)$

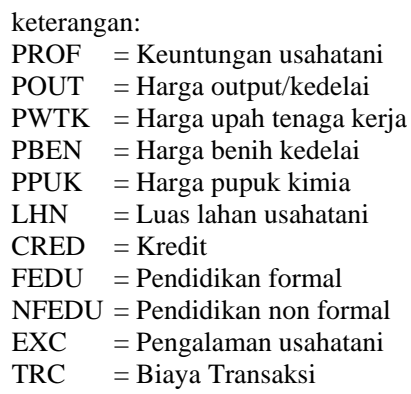

Metode yang digunakan untuk mengetahui dan menghitung biaya transaksi adalah metode deep interview pada setiap kegiatan wawancara dengan petani responden. Metode ini digunakan untuk menelusuri setiap kegiatan yang memungkinkan terdapatnya biaya transaksi didalamnya. 
Sangat penting untuk mengetahui setiap proses yang terjadi dalam usahatani khususnya untuk penelitian ini yaitu usahatani kedelai. Setiap kegiatan yang menghasilkan pertukaran baik pertukaran barang ataupun pertukaran informasi harus diteliti dengan baik. Ketika pertukaran tersebut mengeluarkan biaya maka biaya ini perlu diidentifikasi apakah memenuhi kriteria sebagai biaya transaksi atau tidak (Hardt, 2009).

Beberapa jenis biaya transaksi dalam usahatani terdiri atas biaya informasi, biaya negosiasi, biaya koordinasi, biaya pelaksanaan dan biaya monitoring. Biaya informasi menurut Baye (2010) adalah setiap biaya yang dikeluarkan dalam sebuah usaha untuk mendapatkan informasi mengenai kepentingan usaha, misalnya informasi harga, informasi budidaya, ataupun informasi mengenai sumber pembiayaan. Biaya negosiasi adalah biaya yang dikeluarkan saat melakukan negosiasi dengan pihak yang ingin diajak bekerjasama (Baye, 2010; Williamson, 1989).

Biaya koordinasi adalah biaya yang dikeluarkan pada saat terjadinya penyesuaian kesepakatan antar setiap pelaku usaha yang terlibat (Williamson, 1989). Biaya pelaksanaan adalah biaya yang dikeluarkan untuk setiap kegiatan (Coase dalam Moss, 2013) yang dilakukan. Biaya monitoring adalah biaya yang dikeluarkan karena adanya kegiatan untuk mengawasi pihak lain dalam melaksanakan kontrak (Baye, 2010).

\section{HASIL DAN PEMBAHASAN}

Struktur biaya transaksi pada lokasi penelitian terdiri dari biaya eksplisit (direct dan indirect) dan biaya implisit sesuai dengan penelitian Williamson (1981) yang menemukan biaya eksplisit atau disebut juga biaya informal gift exchange dan biaya implisit atau disebut juga biaya emotional interaction. Kedua jenis biaya ini terbagi menjadi biaya informasi, negosiasi, koordinasi, pelaksanaan, monitoring dan risiko. Keseluruhan biaya ini adalah yang dikeluarkan petani responden mulai dari persiapan sebelum tanam kedelai hingga pada saat penjualan kedelai (pasca panen).

Penentuan masing-masing komponen biaya transaksi berdasarkan dari hasil beberapa penelitian. Biaya informasi, negosiasi dan pelaksanaan sesuai dengan penelitian Anggraini (2005) yang meneliti tentang biaya transaksi pada usahatani padi dan pada usaha perikanan tangkap di Pelabuhanratu, Kabupaten Sukabumi. Biaya monitoring berdasarkan penelitian Sukmadinata (1995) yang meneliti tentang usaha penangkapan ikan. Biaya monitoring timbul karena adanya pengawasan terhadap kegiatan penangkapan ikan yang telah terikat kontrak. Penentuan biaya koordinasi dan risiko berdasarkan penelitian Rudiyanto (2011) pada pengelolaan sea farming yang menunjukkan bahwa jumlah biaya transaksi terbesar adalah pada biaya pelaksanaan setelah kontrak (ex post transaction cost).

\section{Biaya Transaksi pada Pengadaan Sumber Pembiayaan}

Struktur biaya transaksi pada pembiayaan usahatani kedelai di Kabupaten Lamongan terdiri dari biaya 
Tabel 1. Rata-Rata Biaya Transaksi pada Pembiayaan Usahatani Kedelai di Kabupaten Lamongan 2014/2015

\begin{tabular}{lrr}
\hline Komponen Biaya Transaksi & Jumlah (Rp) & Persentase (\%) \\
\hline Biaya informasi & $17.317,08$ & 44,15 \\
Biaya negosiasi & $4.108,33$ & 10,47 \\
Biaya koordinasi & $6.576,28$ & 16,77 \\
Biaya pelaksanaan & $10.753,75$ & 27,42 \\
Biaya monitoring & 469,58 & 1,20 \\
\hline Total & $39.225,03$ & 100,00 \\
\hline
\end{tabular}

informasi, biaya negosiasi, biaya koordinasi, biaya pelaksanaan dan biaya monitoring

Pada Tabel 1 terlihat bahwa komponen biaya transaksi pada pembiayaan usahatani kedelai yang memiliki persentase tertinggi adalah biaya informasi. Kondisi di lokasi penelitian menunjukkan bahwa untuk mendapatkan pinjaman modal dari lembaga keuangan baik formal maupun informal, petani kedelai membutuhkan beberapa informasi dari beberapa orang yang telah lebih dahulu menerima pinjaman modal. Informasi ini dapat diperoleh oleh petani dengan cara melakukan komunikasi baik secara langsung maupun tidak langsung dengan sumber informasi atau pemberi informasi. Komunikasi secara langsung yang dimaksud adalah beberapa petani melakukan perbincangan di warungwarung makan untuk membahas tentang sumber pembiayaan yang tersedia.

Pembahasan menyangkut tentang prosedur apa saja yang harus dilakukan oleh petani untuk mendapatkan pinjaman modal. Biasanya petani akan mengeluarkan biaya untuk memperoleh informasi ini. Biaya ini dikenal dengan sebutan biaya dengar. Petani mengeluarkan uang untuk membayar makanan dan minuman yang dikonsumsi selama melakukan perbincangan.

Selain itu, komunikasi juga biasanya dilakukan melalui media elektronik (handphone). Petani akan melakukan komunikasi dengan pemilik informasi atau dengan orang-orang yang telah menerima pinjaman modal lebih dulu. Biaya ini disebut juga biaya pulsa. Beberapa petani yang mengeluarkan biaya ini adalah petani yang kediamannya jauh dari sumber informasi.

Komponen biaya transaksi dengan persentase tertinggi kedua adalah biaya pelaksanaan. Biaya ini terdiri dari biaya administrasi dan biaya pengurusan dokumen peminjaman modal seperti fotokopi KTP (Kartu Tanda Penduduk), fotokopi KK (Kartu Keluarga) dan fotokopi RUA (Rancangan Usahatani). Dokumen ini merupakan persyaratan yang harus dilengkapi untuk mendapatkan pinjaman modal dari lembaga pembiayaan formal yaitu LKMA. Sedangkan untuk lembaga pembiayaan formal lainnya seperti bank, dibutuhkan fotokopi sertifikat kepemilikan lahan juga terdapat biaya untuk administrasi. Selain itu, terdapat juga jenis biaya pelaksanaan lainnya yaitu biaya antrian yang termasuk biaya implisit. Biaya ini adalah konversi 
dari waktu antrian pada saat pengurusan dokumen peminjaman modal.

Komponen biaya transaksi dengan persentase yang terendah adalah biaya monitoring. Biaya ini berupa biaya yang dikeluarkan petani untuk membayar pekerja suruhan yang bekerja untuk menyelesaikan pengurusan dokumen peminjaman modal. Hal ini sebagian besar dilakukan oleh petani yang tidak sempat mengurus kelengkapan dokumen sebagai persyaratan peminjaman modal. Selain itu juga ada beberapa petani yang menyewa pekerja suruhan karena tidak terlalu mengerti tentang peminjaman modal.

Biaya koordinasi lebih tinggi 5,35\% dari biaya negosiasi. Biaya koordinasi dan biaya negosiasi lebih besar dikeluarkan pada pembiayaan non formal. Hal ini disebabkan pembiayaan non formal hanya berlandaskan pada asas saling percaya sehingga beberapa persyaratan tidak dibuat secara baku melainkan hanya melalui koordinasi dan negosiasi antara pihak peminjam dan pemberi pinjaman.

\section{Biaya Transaksi pada Pengadaan Input Usahatani Kedelai}

Tahap awal sebelum memasuki masa tanam kedelai adalah petani menyiapkan input apa saja yang diperlukan seperti benih kedelai, benih tanaman tumpangsari dan pupuk. Penggunaan input lainnya seperti pestisida dan tenaga kerja dibutuhkan pada pertengahan tanam hingga musim panen. Selama tahapan ini, petani mengeluarkan biaya untuk pengadaan input. Dalam pengadaan input ini, terdapat beberapa jenis biaya transaksi yang akan menambah harga input.

Biaya transaksi yang mempengaruhi input adalah biaya informasi untuk usahatani kedelai, biaya mencari tenaga kerja keluarga dan biaya mempertahankan kontrak tenaga kerja luar keluarga. Keseluruhan biaya transaksi ini akan berpengaruh terhadap harga input kedelai. Dengan biaya ini maka harga input kedelai akan bertambah sehingga biaya pengadaan input akan lebih besar. Namun hal ini tidak disadari oleh petani karena yang dihitung oleh petani hanyalah harga rill untuk input usahatani, sedangkan biaya transaksi yang terbentuk tidak dihitung.

Biaya informasi yang dikeluarkan petani pada pengadaaan input usahatani kedelai adalah biaya informasi untuk mengetahui tentang usahatani kedelai misalnya teknik budidaya atau bagaimana mengatasi hama dan penyakit serta biaya informasi untuk mencari tenaga kerja luar keluarga. Biaya untuk mengetahui informasi mengenai usahatani kedelai dikeluarkan oleh 28 orang petani responden atau sebesar 23,33\%. Petani yang mengeluarkan biaya ini adalah petani yang kekurangan informasi mengenai jenis pestisida apa yang digunakan untuk membasmi hama yang sedang menyerang tanaman kedelai. Banyaknya jenis pestisida yang digunakan akan membuat petani selektif untuk memilih. Dengan demikian secara tidak disadari maka selain dari harga input (pestisida) itu sendiri, petani telah mengeluarkan biaya transaksi yang akan berpengaruh terhadap harga input tersebut. 
Selain biaya informasi mengenai usahatani kedelai, petani responden juga mengeluarkan biaya untuk mencari tenaga kerja luar keluaga. Biaya ini sebagian besar dikeluarkan petani sebelum memasuki musim panen. Permintaan terhadap tenaga kerja yang sangat tinggi pada musim panen membuat petani harus dengan segera mencari tenaga kerja. Petani yang mencari informasi tentang tenaga kerja luar keluarga sebanyak 16 orang atau sebesar 13,33\% dari kategori petani dengan lahan menengah dan lahan luas.

Pada pengadaan input usahatani kedelai juga terdapat biaya negosiasi berupa biaya keakraban. Biaya ini dikeluarkan petani untuk mempertahankan kontrak dengan tenaga kerja luar keluarga. Biasanya petani akan mengajak tenaga kerja luar keluarga untuk berbincang-bincang di warung kopi atau di warung makan. Keseluruhan biaya makan dan minum akan dibayarkan oleh petani. Biaya inilah yang termasuk kedalam biaya negosiasi (biaya keakraban).

Biaya ini antara lain biaya mempertahankan kontrak (pajak lahan), biaya rapat kelompok tani, iuran kelompok tani dan iuran desa. Keseluruhan biaya ini tidak terkait dengan sumber pembiayaan, input dan output usahatani kedelai.

Biaya negosiasi yaitu biaya mempertahankan kontrak lahan (pajak lahan) merupakan komponen biaya transaksi yang terbesar diantara biaya transaksi lainnya. Biaya ini dikeluarkan petani responden sebesar Rp 81.375. Sesuai dengan hasil penelitian Anggraini (2005) bahwa pajak lahan (Pajak Bumi dan
Bangunan/PBB) merupakan biaya transaksi. Hal ini disebabkan sifat PBB yang dibayarkan oleh petani atau pemilik lahan adalah untuk mempertahankan kontrak atas lahan dan bangunan yang dimilikinya kepada pemerintah.

Nilai pajak ditentukan berdasarkan harga lahan yang berlaku pada tahun tersebut sehingga setiap tahunnya bisa mengalami perubahan. Faktor penentu harga lahan adalah berdasarkan letak lahan dan kesuburan lahan. Lahan yang lokasinya dekat dengan pusat-pusat perekonomian seperti pasar atau jalan raya akan memiliki harga lahan yang lebih tinggi.

Selain biaya negosiasi terdapat pula biaya koordinasi berupa biaya rapat dan biaya iuran kelompok tani. Biaya rapat adalah keseluruhan biaya yang dikeluarkan petani responden pada saat akan menghadiri rapat kelompok tani. Biaya ini bisa termasuk biaya makan dan minum untuk konsumsi petani. Sedangkan biaya iuran kelompok tani adalah iuran yang harus dibayarkan kelompok tani sebagai anggota dari kelompok tani. Iuran kelompok tani dibayarkan setiap dua kali dalam satu tahun. Iuran ini berbeda-beda jumlahnya untuk masing-masing kelompok tani seperti Rp 2.500, Rp 3.500 hingga Rp 5.000 per 6 bulan.

Iuran lain yang juga dikeluarkan oleh petani adalah iuran desa. Iuran ini dikeluarkan satu kali dalam satu tahun. Jumlah iuran berbeda-beda untuk setiap desa mulai dari Rp 5.000 hingga Rp 10.000. Iuran desa termasuk kedalam biaya monitoring karena biaya ini dikeluarkan untuk menjaga keamanan 
bersama dalam satu desa termasuk keamanan bersama termasuk dalam menjaga hasil panen dan peralatanperalatan usahatani yang dimiliki petani.

\section{Biaya Transaksi pada Pengadaan Output Usahatani Kedelai}

Saat memasuki musim panen hingga pasca panen, petani melakukan beberapa kegiatan yang memunculkan biaya transaksi. Biaya ini diantaranya adalah biaya untuk mencari informasi mengenai harga kedelai, biaya untuk upah supir pengantar hasil panen dan juga biaya risiko. Biaya ini akan berpengaruh terhadap harga output kedelai. Dengan tidak disadari oleh petani responden bahwa keberadaan biaya ini akan mengurangi harga output.

Ketika musim panen tiba, beberapa petani akan mencari informasi mengenai harga kedelai yang berlaku di pasar serta harga yang ditentukan oleh pedagang kecamatan. Jumlah petani responden yang mencari informasi harga ini sebanyak 8 orang atau sebesar 6,66\%. Petani ini termasuk petani yang kediamannya dan lokasi lahannya jauh dari pusat kecamatan sehingga untuk mengetahui tentang informasi apa saja termasuk informasi harga sangat sulit. Dengan begitu petani akan mengeluarkan biaya misalnya menemui petani lain atau langsung menemui pedagang kecamatan. Biaya inilah yang termasuk biaya mencari informasi harga kedelai.

Jenis biaya lain pada pengadaan output adalah biaya untuk membayar upah supir pengantar hasil panen. Sebanyak 26 orang atau sebesar 21,66\% petani dengan kategori lahan sempit yang mengeluarkan biaya ini. Hal ini dilakukan karena jumlah hasil panen tidak memenuhi jumlah yang ditentukan oleh pedagang perantara. Jika hasil panen mencapai 1 truk atau \pm 3 ton maka pedagang perantara akan menjemput hasil panen tersebut namun jika tidak maka petani harus mengantarkannya sendiri. Oleh karena itu beberapa petani dengan hasil panen yang sedikit mengumpulkan hasil panennya agar memenuhi persyaratan tersebut. Setelah itu mereka akan mengubungi pedagang perantara. Supir yang mengangkut hasil panen memang disediakan oleh pedagang perantara, namun beberapa dari petani tersebut mengeluarkan uangnya secara sukarela untuk supir pengangkut hasil panen tersebut.

Dalam perjalanan menuju pedagang perantara terkadang ada kedelai yang rusak, apalagi pada saat turun hujan yang tidak terduga. Oleh sebab itu ada beberapa petani yang melakukan antisipasi berupa menyiapkan plastik ataupun terpal berukuran sedang untuk menutup kedelai saat dalam perjalanan menuju pedagang perantara. Biaya ini termasuk kedalam biaya untuk menghindari risiko kedelai rusak. Berbeda halnya ketika kedelai sudah mengalami kerusakan saat tiba di pedagang perantara. Harga yang diterima akan otomatis berkurang. Harga yang hilang ini termasuk kedalam biaya pengendalian risiko. Sebanyak 6 orang petani responden atau sebesar 5\% akan mengeluarkan biaya ini sebagai pengendalian terhadap risiko yang ditimbulkan karena kedelai yang rusak. 
Jumlah Biaya Transaksi pada Usahatani Kedelai

Jumlah biaya transaksi yang terdapat pada usahatani kedelai sebesar Rp 144.120,86. Keseluruhan jumlah biaya transaksi tersaji pada Tabel 2. Komponen biaya transaksi untuk setiap kegiatan pengadaan sumber pembiayaan, pengadaan input, pengadaan output serta kegiatan lainnya didominasi oleh biaya negosiasi sebesar 60,30\%. Besarnya jumlah biaya mempertahankan kontrak lahan (pajak lahan) menjadi faktor utama penentu nilai dari komponen biaya transaksi ini. Kewajiban petani responden untuk membayar Pajak Bumi dan Bangunan (PBB) membuat petani responden akan selalu mengadakan kegiatan negosiasi dengan pemerintah. Hal ini dilakukan agar petani dapat terus mempertahankan lahan dan bangunan yang dimilikinya.
Komponen biaya transaksi dengan persentase terbesar setelah biaya negosiasi adalah biaya informasi. Sebagaimana telah diketahui bahwa biaya informasi mendominasi hampir seluruh kegiatan yang dilakukan petani selama melakukan usahatani kedelai misalnya pada kegiatan pengadaan sumber pembiayaan, pengadaan input dan pengadaan output. Biaya informasi untuk usahatani memiliki persentase sebesar $14.07 \%$. Kurangnya akses yang dimiliki petani untuk mendapatkan informasi membuat petani harus selalu mengeluarkan biaya untuk memperoleh informasi. Walaupun begitu biaya yang dikeluarkan ini terkadang belum diketahui oleh petani. Pengeluran biaya ini tidak dihitung sebagaimana biaya usahatani lainnya.

Tabel 2. Jumlah Biaya Transaksi pada Usahatani Kedelai di Kabupaten Lamongan 2014/2015

\begin{tabular}{|c|c|c|c|c|c|}
\hline Jenis biaya transaksi & $\begin{array}{l}\text { Pengadaan } \\
\text { sumber } \\
\text { pembiayaan }\end{array}$ & $\begin{array}{c}\text { Pengadaan } \\
\text { input }\end{array}$ & $\begin{array}{c}\text { Pengadaan } \\
\text { output }\end{array}$ & $\begin{array}{l}\text { Jumlah } \\
\text { (Rp) }\end{array}$ & $\begin{array}{c}\text { Persentase } \\
\text { (\%) }\end{array}$ \\
\hline Biaya informasi & & & & & \\
\hline $\begin{array}{l}\text { - Explicit/direct cost } \\
\text { Biaya negosiasi }\end{array}$ & $17.317,08$ & $2.512,50$ & 445,83 & $20.275,42$ & 14,07 \\
\hline $\begin{array}{l}\text { - Explicit/direct cost } \\
\text { Biaya koordinasi }\end{array}$ & $4.108,33$ & $82.800,00$ & & $86.908,33$ & 60,30 \\
\hline $\begin{array}{l}\text { - Explicit/direct cost } \\
\text { - Implicit cost }\end{array}$ & $\begin{array}{r}6.175,00 \\
401,28\end{array}$ & $11.033,33$ & & $\begin{array}{r}17.208,33 \\
401,28\end{array}$ & 12,22 \\
\hline Biaya pelaksanaan & & & & & \\
\hline - Explicit/direct cost & $10.510,83$ & & 862,50 & $11.373,33$ & \\
\hline - Implicit cost & 201,25 & & & 201,25 & 8,03 \\
\hline Biaya monitoring & & & & & \\
\hline $\begin{array}{l}\text { - Explicit/direct cost } \\
\text { Biaya risiko }\end{array}$ & 469,58 & $5.625,00$ & & $6.094,58$ & 4,23 \\
\hline - Explicit/indirect cost & & & $1.658,33$ & $1.658,33$ & 1,15 \\
\hline Total biaya transaksi & & & & $144.120,86$ & 100,00 \\
\hline
\end{tabular}


Tabel 3. Perbandingan Jenis Biaya Transaksi pada Usahatani Kedelai di Kabupaten Lamongan 2014/2015

\begin{tabular}{lrc}
\hline Jenis & Jumlah (Rp & Presentase (\%) \\
\hline Biaya eksplisit & $143.518,33$ & 99,58 \\
Biaya implisit & 602,53 & 0,42 \\
\hline Total & $144.120,86$ & 100,00 \\
\hline
\end{tabular}

Pada Tabel 3 terlihat bahwa terdapat perbedaan yang sangat besar antara biaya eksplisit dan biaya implisit. Sebagaimana yang dijelaskan oleh Williamson (1989) bahwa biaya eksplisit adalah biaya informal gift exchange yaitu biaya dikeluarkan dalam setiap pertukaran sedangkan biaya implisit adalah biaya emotional interaction yaitu biaya yang dikeluarkan pada setiap kegiatan yang akan menimbulkan interaksi emosi di dalam diri pelaku usaha yang jika dihitung akan menghasilkan nilai ketika melakukan pekerjaan lain. Dilanjutkan oleh D’Hondt (2008) bahwa biaya implisit menyerupai biaya opportunity cost. Jika disinkronkan maka yang membedakan biaya opportunity (imbangan) dengan biaya implisit adalah interaksi emosional yang ditimbulkan oleh pelaku usaha ketika melakukan kegiatan lain disaat seharusnya ada kegiatan lainnya yang dikorbankan. Penghitungan biaya implisit adalah dengan melakukan konversi terhadap keseluruhan nilai yang seharusnya didapatkan dengan waktu yang dikorbankan.

Jika biaya imbangan akan menghitung keseluruhan nilai yang seharusnya didapatkan saat melakukan pekerjaan korbanan, maka biaya implisit hanya akan menghitung kegiatan yang menimbulkan interaksi emosional dalam diri pelaku usaha saja. Misalnya untuk kegiatan pengurusan dokumen peminjaman modal, jika yang ingin dihitung adalah biaya imbangan maka keseluruhan nilai yang seharusnya didapatkan dihitung pada saat pengurusan dokumen dilakukan, mulai dari penyiapan dokumen hingga selesai (karena ada pekerjaan yang dikorbankan). Sedangkan jika yang ingin dihitung adalah biaya implisit maka yang dihitung hanyalah biaya pada saat melakukan antrian dalam pengurusan dokumen. Pada saat melakukan antrian, tetap ada nilai yang seharusnya diterima pelaku usaha jika melakukan kegiatan lain (sama dengan biaya imbangan) namun inti dari biaya implisit adalah melibatkan emosi dalam diri pelaku. Williamson (1989) mengatakan bahwa ketika ada interaksi emosional dalam diri pelaku usaha ketika melakukan kegiatan transaksi maka hal tersebut termasuk dalam biaya emotional interaction. Pada saat melakukan antrian, terdapat interaksi emosional dalam diri petani kedelai. Interkasi emosional yang dimaksud adalah adanya pemikiranpemikiran lain yang menggangu dan adanya kegiatan lain yang menunggu sedangkan petani kedelai harus mengantri demi untuk menyelesaikan pengurusan dokumen peminjaman modal. Jadi yang dihitung hanya biaya antriannya saja, sedangkan biaya untuk kegiatan pengurusan dokumen mulai dari awal 
hingga selesai akan termasuk kedalam jenis biaya transaksi lainnya yaitu biaya pelaksanaan.

Kegiatan lain selain dari pengurusan dokumen yang menimbulkan biaya implisit adalah kegiatan pertemuan pada saat peminjaman dan pengembalian modal. Hal ini hanya terjadi pada petani responden yang memiliki pinjaman modal pada sumber pembiayaan formal. Pada saat peminjaman modal misalnya di bank, petani akan melakukan antrian dengan nasabah lain. Begitu juga dengan peminjaman modal pada LKMA (Lembaga Keuangan Mikro Agribisnis). Pada saat dana telah dicairkan oleh pengurus LKMA, maka petani akan dikumpulkan untuk dibagikan pinjaman tersebut. Namun kegiatan pembagian ini tidak langsung dibagikan melainkan akan dirangkaikan dengan kegiatan lainnya misalnya untuk membahas masalah usahatani kedelai atau pembahasan lainnya.

Sama halnya pada saat pengembalian pinjaman. Pengembalian pinjaman di bank juga harus mengantri dengan nasabah lain. Begitu juga saat melakukan pengembalian modal di LKMA harus mengantri dengan petani lainnya yang juga sudah jatuh tempo pembayarannya.

\section{Pengaruh Biaya Transaksi terhadap Keuntungan Usahatani Kedelai}

Setelah mengetahui struktur biaya transaksi pada usahatani kedelai, tujuan penelitian selanjutnya adalah untuk mengetahui bagaimana pengaruh biaya transaksi terhadap keuntungan usahatani kedelai. Keuntungan usahatani diperoleh dari total penerimaan yang dikurangi dengan total biaya usahatani.

Berdasarkan Tabel 4 diketahui bahwa penerimaan usahatani kedelai terdiri dari penerimaan untuk kedelai itu sendiri dan penerimaan dari tanaman tumpangsari yaitu jagung atau kacang hijau. Untuk biaya usahatani sudah termasuk biaya untuk usahatani kedelai dan juga biaya tumpangsari. Sehingga rata-rata keuntungan yang diperoleh untuk satu hektar dalam satu tahun usahatani kedelai yaitu sebesar Rp 3.685.282,39.

Keuntungan ini diperoleh setelah dikurangi dengan total biaya usahatani

Tabel 4. Penerimaan dan Keuntungan Usahatani Kedelai di Kabupaten Lamongan 2014/2015

\begin{tabular}{lcrr}
\hline \multicolumn{1}{c}{ Variabel } & Satuan & \multicolumn{2}{c}{ Jumlah (Rp) } \\
\hline Produksi kedelai & $\mathrm{kg}$ & $1.539,08$ & \\
Harga kedelai & $\mathrm{Rp} / \mathrm{kg}$ & $6.683,33$ & \\
Penerimaan kedelai & $\mathrm{Rp}$ & & $10.184 .200,00$ \\
Produksi tanaman tumpangsari & $\mathrm{kg}$ & 222,63 & \\
Harga tanaman tumpangsari & $\mathrm{Rp} / \mathrm{kg}$ & $1.270,83$ & \\
Penerimaan tanaman tumpangsari & $\mathrm{Rp}$ & & $556.562,50$ \\
Penerimaan usahatani kedelai & $\mathrm{Rp}$ & & $10.740 .762,50$ \\
Biaya usahatani kedelai & $\mathrm{Rp}$ & & $7.055 .480,11$ \\
\hline Keuntungan usahatani kedelai & $\mathrm{Rp}$ & & $3.685 .282,39$ \\
\hline
\end{tabular}


Tabel 5. Perbandingan Biaya Transaksi Terhadap Biaya dan Keuntungan Usahatani Kedelai di Kabupaten Lamongan 2014/2015

\begin{tabular}{lrr}
\hline Uraian & Jumlah (Rp) & Rasio (\%) \\
\hline Biaya usahatani & $7.055 .480,11$ & 2,04 \\
Keuntungan usahatani & $3.685 .282,39$ & 3,91 \\
\hline Jumlah biaya transaksi/Rp1 juta biaya usahatani & & $20.426,80$ \\
\hline Jumlah biaya transaksi/Rp1 juta keuntungan & & $39.107,14$ \\
\hline
\end{tabular}

sebesar Rp 7.055.480,11. Setelah diketahui total biaya dan total keuntungan usahatani, maka akan diperoleh rasio/ perbandingan biaya transaksi terhadap biaya usahatani dan juga terhadap keuntungan usahatani.

Pada Tabel 5 terlihat bahwa rasio biaya transaksi terhadap biaya usahatani kedelai sebesar 2,04\%. Selain itu diketahui bahwa setiap Rp 1 juta biaya usahatani yang dikeluarkan, maka biaya transaksi yang juga harus dikeluarkan sebesar Rp 20.426,80. Hal ini berarti bahwa total biaya yang seharusnya dikeluarkan petani kedelai dalam usahataninya jika dihitung dengan biaya transaksi yaitu sebesar Rp 7.199.600,97.

Selain rasio terhadap biaya usahatani juga terdapat rasio biaya transaksi terhadap keuntungan usahatani. Rasio yang diperoleh dari Tabel 7 yaitu sebesar 3,91\%. Dengan perhitungan bahwa setiap Rp 1 juta keuntungan usahatani, akan dikeluarkan biaya transaksi sebesar Rp $39.107,14$. Sehingga jika dihitung total keuntungan setelah dikurangi dengan biaya transaksi, maka didapatkan total keuntungan sebesar Rp 3.541.161,53.

Sebelum melihat pengaruh biaya transaski terhadap keuntungan usahatani, maka akan diketahui terlebih dahulu faktor-faktor lain yang juga mempengaruhi keuntungan usahatani. Faktor- faktor tersebut seperti luas lahan dan biaya usahatani. Sesuai dengan penelitian Tahir, dkk (2010) bahwa luas lahan sangat berpengaruh terhadap keuntungan usahatani. Semakin besar luas lahan yang dimiliki oleh petani maka akan semakin tinggi keuntungan yang diterima oleh petani. Hal ini disebabkan peningkatan jumlah produksi yang juga semakin tinggi. Penelitian yang dilaksanakan di Gorontalo, Sulawesi Selatan ini menunjukkan bahwa penurunan luas lahan kedelai di Gorontalo menyebabkan menurunnya produksi kedelai. Penetapan harga kedelai yang cenderung tidak berubah membuat keuntungan yang diterima petani semakin rendah.

Faktor lainnya seperti biaya usahatani juga menjadi faktor yang berpengaruh terhadap keuntungan usahatani. Dikatakan oleh Firdaus (2007) bahwa semakin tinggi biaya input yang dikeluarkan oleh petani maka akan semakin rendah keuntungan yang didapatkan. Penelitian yang membandingkan usahatani kedelai di Jember dan Banyuwangi, Jawa Timur ini menunjukkan bahwa keuntungan usahatani kedelai di Jember lebih tinggi daripada keuntungan usahatani kedelai di Banyuwangi. Hal ini disebabkan penggunaan biaya upah tenaga kerja yang lebih tinggi di Banyuwangi. 
Biaya transaksi dapat menjadi faktor yang mempengaruhi keuntungan usahatani dikatakan oleh Martin et. al. (2010) karena biaya transaksi memunculkan kondisi uncertainty. Kondisi ini akan memunculkan sebuah biaya yang disebut biaya ketidakpastian. Selain pada usaha skala makro, kondisi ketidakpastian juga selalu terjadi pada usaha mikro salah satunya adalah usahatani. Untuk melakukan pengukuran terhadap biaya ini diperlukan managemen biaya transaksi yang efektif karena hal ini juga menyangkut tentang peramalan (forecasting). Hasil dari pendugaan parameter untuk melihat faktor-faktor yang mempengaruhi keuntungan usahatani kedelai terdapat pada Tabel 6.

Berdasarkan hasil pendugaan pada Tabel 6 terlihat bahwa faktor yang berpengaruh signifikan pada taraf $10 \%$, yaitu variabel harga upah tenaga kerja, harga benih, harga pupuk, luas lahan, kredit, pendidikan non formal dan biaya transaksi. Sedangkan faktor yang tidak berpengaruh signifikan yaitu variabel harga output, pendidikan formal dan pengalaman usahatani.

Variabel harga output tidak berpengaruh signifikan walaupun tanda parameter dugaan adalah positif terhadap keuntungan usahatani kedelai. Harga output atau harga kedelai tidak berpengaruh signifikan karena pada lokasi penelitian, harga kedelai yang diterima oleh petani tidak bervariasi. Dengan harga yang sama, tidak berarti memberikan pengaruh yang sama untuk setiap keuntungan petani. Harga tertinggi yang diterima petani yaitu sebesar Rp 6.800 dan harga terendah yaitu sebesar Rp 6.200. Penetapan harga kedelai ditentukan oleh pedagang berdasarkan kualitas kedelai yang dihasilkan.

Variabel upah tenaga kerja, harga benih dan harga pupuk merupakan komponen dari harga input pada usahatani kedelai di lokasi penelitian. Ketiga variabel ini berpengaruh signifikan terhadap pembentukan modal dengan tanda parameter negatif. Hal ini

Tabel 6. Hasil Pendugaan Parameter Persamaan Keuntungan Usahatani pada Usahatani Kedelai di Kabupaten Lamongan 2014/2015

\begin{tabular}{lrrrrr}
\hline \multicolumn{1}{c}{ Variabel } & $\begin{array}{c}\text { Parameter } \\
\text { Dugaan }\end{array}$ & $\begin{array}{c}\text { Standar } \\
\text { Error }\end{array}$ & Nilai t & Pr $>|\mathbf{t}|$ & Elastisitas \\
\hline Konstanta & 41146509,00 & 35059891,00 & 1,17 & 0,24 & \\
Harga output & 1018,98 & 2931,31 & 0,35 & 0,73 & 1,96 \\
Upah tenaga kerja & $-0,86$ & 0,17 & $-5,03$ & $<, 00$ & $-1,37$ \\
Harga benih & $-19,71$ & 7,47 & $-2,64$ & 0,00 & $-0,39$ \\
Harga pupuk & $-6871,46$ & 3419,58 & $-2,01$ & 0,04 & $-12,59$ \\
Luas lahan & 7711857,00 & 1749396,00 & 4,41 & $<, 00$ & 1,61 \\
Kredit & 27,52 & 12,42 & 2,22 & 0,03 & 1,09 \\
Pendidikan formal & $-301793,00$ & 238783,30 & $-1,26$ & 0,21 & $-0,57$ \\
Pendidikan non formal & 4893805,00 & 1408824,00 & 3,47 & 0,00 & 0,43 \\
Pengalaman usahatani & 46522,66 & 59674,84 & 0,78 & 0,44 & 0,38 \\
Biaya Transaksi & $-7,57$ & 2,28 & $-3,31$ & 0,00 & $-0,82$ \\
\hline
\end{tabular}


berarti bahwa semakin tinggi nilai dari variabel ini, maka keuntungan akan semakin rendah dan begitu pula sebaliknya. Sama halnya dengan penelitian Firdaus (2007) bahwa semakin tinggi harga input yang dikeluarkan oleh petani maka akan semakin rendah keuntungan yang didapatkan. Penelitian yang membandingan usahatani kedelai di Jember dan Banyuwangi, Jawa Timur ini menunjukkan bahwa keuntungan usahatani kedelai di Jember lebih tinggi daripada keuntungan usahatani kedelai di Banyuwangi. Hal ini disebabkan penggunaan biaya upah tenaga kerja yang lebih tinggi di Banyuwangi.

Variabel luas lahan berpengaruh positif dan signifikan terhadap keuntungan usahatani. Semakin luas lahan yang dimiliki oleh petani maka keuntungan usahatani juga akan semakin tinggi. Rata-rata luas lahan yang dikuasai oleh petani kedelai di lokasi penelitian yaitu sebesar 0,76 hektar. Sesuai dengan penelitian Tahir, dkk (2010) bahwa luas lahan sangat berpengaruh terhadap keuntungan usahatani. Semakin besar luas lahan yang dimiliki oleh petani maka akan semakin tinggi keuntungan yang diterima oleh petani. Hal ini disebabkan peningkatan jumlah produksi yang juga semakin tinggi. Penelitian yang dilaksanakan di Gorontalo, Sulawesi Selatan ini menunjukkan bahwa penurunan luas lahan kedelai di Gorontalo menyebabkan menurunnya tingkat produksi kedelai.

Jenis kredit yang diterima oleh petani kedelai di lokasi penelitian adalah kredit modal kerja. Sumber kredit berasal dari lembaga keuangan formal dan lembaga keuangan non formal. Berdasarkan hasil pendugaan, kredit berpengaruh positif dan signifikan terhadap keuntungan usahatani. Sesuai yang terjadi di lokasi penelitian bahwa penggunaan kredit memang ditujukan untuk kegiatan usahatani. Sebelum musim tanam kedelai tiba, petani akan menerima kredit untuk digunakan membeli benih, pupuk dan pestisida. Sejalan dengan penelitian Kohansal, dkk (2008) bahwa adanya fasilitas kredit akan mengurangi financial constrain dan meningkatkan produktivitas. Keuntungan petani akan meningkat seiring dengan penggunaan kredit. Kemunculan lembaga keuangan yang berada di perdesaan akan berpengaruh positif terhadap peningkatan keuntungan petani sehingga kesejahteraan petani juga akan meningkat.

Variabel pendidikan non formal petani berpengaruh positif dan signifikan terhadap keuntungan usahatani. Pada lokasi penelitian, pendidikan non formal dimiliki petani kedelai melalui keikutsertaan dalam pelatihan ataupun penyuluhan yang dilakukan oleh Dinas Pertanian Kabupaten Lamongan, Unit Pelaksana Teknis (UPT) masing-masing kecamatan ataupun dari kelompok tani. Petani responden yang mendapatkan pendidikan non formal sebesar 27,50\%. Hasil pendugaan menjelaskan bahwa pendidikan non formal yang dimiliki petani kedelai berpengaruh positif terhadap keuntungan usahatani kedelai. Hal ini berarti bahwa pengetahuan dan keahlian yang diperoleh dalam pelatihan ataupun penyuluhan dapat meningkatkan keuntungan yang diperoleh oleh petani kedelai. 
Selain pendidikan non formal, petani responden juga mendapatkan pendidikan formal. Sebesar 40,83\% petani responden adalah tamatan SD, 15\% tamatan SLTP, 18,33\% tamatan SLTA, 1,67\% sarjana muda dan sisanya $24,17 \%$ tidak tamat SD/Sederajat. Walaupun $75,83 \%$ petani responden memperoleh pendidikan formal namun hasil pendugaan menunjukkan bahwa pendidikan formal tidak berpengaruh signifikan terhadap keuntungan usahatani kedelai. Sebagaimana yang terjadi di lokasi penelitian bahwa petani dengan pendidikan rendah namun memiliki lahan yang luas maka tingkat keuntungannya lebih tinggi daripada keuntungan usahatani petani yang memiliki pendidikan tinggi namun memiliki lahan yang termasuk kategori menengah. Luas lahan lebih besar dan signifikan pengaruhnya terhadap keuntungan usahatani dibandingkan pendidikan formal. Sama halnya dengan pengalaman usahatani, hasil pendugaan menunjukkan bahwa pengalaman usahatani tidak berpengaruh signifikan terhadap keuntungan usahatani. Sebesar 26,67\% petani responden memiliki pengalaman usahatani yaitu selama 20 30 tahun namun jika dilihat dari keuntungan usahatani yang diperoleh sangat beragam. Hal ini menunjukkan bahwa pengalaman tidak menentukan tingkat keuntungan yang diperoleh oleh petani responden.

Variabel biaya transaksi berpengaruh negatif dan signifikan terhadap keuntungan usahatani kedelai. Komponen biaya transaksi yang memiliki persentase tertinggi adalah biaya negosiasi sebesar 60,30\% dati total biaya transaksi. Sesuai dengan struktur biaya transaksi yang terbentuk memperlihatkan bahwa biaya transaksi pada pengadaan input, output dan sumber pembiayaan memberikan pengaruh negatif terhadap keuntungan usahatani kedelai. Hal ini sesuai dengan penelitian Martin et. al. (2010) dan Mayvani (2011) yang mengatakan bahwa biaya transaksi dapat menjadi faktor yang mempengaruhi keuntungan karena adanya biaya transaksi menunjukkan tidak adanya pemusatan kegiatan pada satu titik (aglomerasi). Hal ini mengakibatkan terjadinya kegagalan pasar dan juga terjadinya penurunan tingkat keuntungan usaha yang sangat rendah.

\section{SIMPULAN DAN SARAN}

\section{Simpulan}

Berdasarkan hasil penelitian pengaruh biaya transaksi terhadap keuntungan usahatani kedelai di Kabupaten Lamongan, Jawa Timur diperoleh simpulan sebagai berikut:

1. Biaya transaksi yang terbentuk pada usahatani kedelai adalah biaya informasi, biaya negosiasi, biaya koordinasi, biaya pelaksanaan, biaya monitoring dan biaya risiko. Masingmasing komponen biaya terdapat pada pengadaan sumber pembiayaan, pengadaan input dan output usahatani kedelai. Jumlah biaya transaksi pada usahatani kedelai sebesar Rp 144.120,86. Biaya negosiasi merupakan komponen biaya transaksi yang memiliki persentase terbesar yaitu $60,30 \%$.

2. Biaya transaksi berpengaruh negatif dan signifikan terhadap keuntungan 
usahatani. Faktor lain yang juga berpengaruh negatif yaitu variabel upah tenaga kerja, harga benih dan harga pupuk. Sedangkan faktor yang berpengaruh positif terhadap keuntungan usahatani kedelai yaitu variabel luas lahan, kredit dan pendidikan non formal.

\section{Saran}

1. Diperlukan kerjasama dari pihak penyuluh untuk memberikan pengetahuan yang lebih banyak mengenai biaya transaksi agar keberadaan biaya transaksi dapat diketahui sehingga dapat diminimalkan.

2. Kebutuhan akan infrastruktur yang memadai sangat diperlukan untuk meminimalkan biaya transaksi. Jarak antara lahan petani dengan pasar sebagai sumber informasi yang cukup jauh membuat petani mengeluarkan biaya-biaya yang tidak diperhitungkan dalam biaya usahatani. selain itu, keterlibatan dan keaktifan kelompok tani juga sangat diperlukan untuk mengurangi biaya transaksi. Koordinasi yang kuat antar petani bisa mengurangi biaya informasi, biaya koordinasi, biaya pelaksanaan dan juga biaya negosiasi.

\section{DAFTAR PUSTAKA}

Anggraini E. 2005. Analisis Biaya Transaksi dan Penerimaan Nelayan dan Petani di Pelabuhanratu Kabupaten Sukabumi. [Tesis]. Institut Pertanian Bogor, Bogor.

Baye MR. 2010. Managerial Economics and Business Strategy. Mc Graw-
Hill Companies, Inc. 1221 Avenue of the Americas, New York.

Berge LIO, Kjetil B, Bertil T. 2011. Human and Financial Capital for Microenterprise Development; Evidence from a Field and Lab Experiment. CMI (Chr. Michelsen Institute) Working Paper.

[BPS] Badan Pusat Statistik. 2014. Luas Panen, Produktivitas dan Produksi Kedelai di Indonesia. www.bps.go.id. Diakses 08 Agustus 2014.

D’Hondt C. 2008. Transaction Cost Analysis A-Z. EDHEC. France

Firdaus, M. 2007. Analisis Daya Saing Kedelai di Jawa Timur. Jurnal Sosial Ekonomi Pertanian Vol.1 No.2, November 2007.

Hardt L. 2009. The History of Transaction Cost Economics and Its Recent Development. Erasmus Journal for Philosophy and Economics, Volume 2, Issue 1, Summer 2009, pp. 29-51.

Lind DA, Marchal WG dan Wathen SA. 2008. Teknik-teknik Statistika dalam Bisnis dan Ekonomi. Salemba Empat: Jakarta.

Martins R, Serra FR, Leite AS, Ferreira MP dan Li D. 2010. Transaction Cost Theory influence in strategy research: A review through a bibliometric study in leading journals. Working paper No.61/2010 April. globAdvantage Center of Research in International Business and Strategy.

Moss CB. 2013. Agricultural Finance. Routledge. 711 Third Avenue, New York. 
Rudiyanto BY. 2011. Analisis Kelembagaan dan Biaya Transaksi dalam Pengelolaan Sea Farming di Pulau Panggang Kabupaten Administrasi Kepulauan Seribu. [Tesis]. Institut Pertanian Bogor, Bogor.

Sukmadinata T. 1995. Kajian Kelembagaan Transaksi dalam Pemasaran Hasil Usaha Penangkapan Ikan di Jawa Timur. [Disertasi]. Institut Pertanian Bogor, Bogor.

Tahir AG, Darwanto DH, Mulyo JH dan Jamhari. 2010. Analsisi Efisiensi Produksi Sistem Usahatani Kedelai di Sulawesi Selatan. Jurnal Agro Ekonomi Vo. 28 No. 2, Oktober 2010: 133-151.

Williamson OE. 1981. The Economics of Organization: The Transaction Cost Approach. The American Journal of Sociology, Vol.87 No.3 (Nov. 1981), 548-577.

Williamson OE. 1989. Transaction Cost Economics: An Introduction. Handbook of Industrial Organization, Volume I. Elsevier Science Publishers B.V. 1989. University of California, Berkeley. 